\title{
HIV-associated salivary gland disease: a role for BK birus
}

\author{
Liesl Kerlyn Jeffers ${ }^{3^{*}}$, Jennifer Webster-Cyriaque ${ }^{1,2,3,4}$ \\ From $12^{\text {th }}$ International Conference on Malignancies in AIDS and Other Acquired Immunodeficiencies \\ (ICMAOI) \\ Bethesda, MD, USA. 26-27 April, 2010
}

HIV-associated salivary gland disease (HIV-SGD) is disfiguring and causes significant morbidity in the HIV population. Evidence detailing the epidemiology of HIV-SGD suggests the involvement of a viral opportunist in its pathogenesis, yet the specific etiology of HIV-SGD remains unclear. To determine the role for an opportunistic virus as the etiologic agent of HIV-SGD, we hypothesized that HIV-SGD was a manifestation of primary infection or reactivation with a DNA tumor virus, BKV, during immune suppression. The central hypothesis of this work is that viral pathogenesis is essential to the development of salivary gland disease. Results show for the first time that polyomavirus, BKV, is associated with HIV-SGD. BKV DNA, RNA, and protein were consistently detected in salivary gland biopsies and in the peripheral blood and oral fluids from HIV-SGD patients and not in control subjects. To confirm the in vivo findings, an in vitro model was created whereby parotid and submandibular salivary gland cells were productively infected with $\mathrm{BKV}$, demonstrating each part of the viral life cycle. Salivary gland tropism was confirmed and the BKV receptor on salivary gland cells was defined. BKV transmission and pathogenesis is not well understood. Importantly, these studies suggest a role for BKV in HIV-SGD and that BKV transmission may occur via the oral route. The longterm goal of this project is to make critical strides toward understanding the etiology of SGD in order to go beyond the ineffective palliative treatment that is currently the standard of care.

\section{Acknowledgements}

This work was supported by NIDCR OHARA 1 U01 Al068636-01.

\footnotetext{
${ }^{*}$ Correspondence: lieslj@med.unc.edu

${ }^{3}$ Department of Microbiology and Immunology, University of North Carolina

School of Medicine, Chapel Hill, NC, USA

Full list of author information is available at the end of the article
}

This article has been published as part of Infectious Agents and Cancer Volume 5 Supplement 1, 2010: Proceedings of the $12^{\text {th }}$ International Conference on Malignancies in AIDS and Other Acquired Immunodeficiencies (ICMAOI). The full contents of the supplement are available online at http://www.biomedcentral.com/1750-9378/5?issue=S1.

\section{Author details}

'Lineberger Cancer Center, University of North Carolina, Chapel Hill, NC, USA. ${ }^{2}$ Division of Infectious Disease, University of North Carolina, Chapel Hill, NC, USA. ${ }^{3}$ Department of Microbiology and Immunology, University of North Carolina School of Medicine, Chapel Hill, NC, USA. ${ }^{4}$ Department of Dental Ecology, University of North Carolina School of Dentistry Chapel Hill, NC, USA.

Published: 11 October 2010

doi:10.1186/1750-9378-5-S1-A33

Cite this article as: Jeffers and Webster-Cyriaque: HIV-associated salivary gland disease: a role for BK birus. Infectious Agents and Cancer 2010 5(Suppl 1):A33.

\section{Submit your next manuscript to BioMed Central and take full advantage of: \\ - Convenient online submission \\ - Thorough peer review \\ - No space constraints or color figure charges \\ - Immediate publication on acceptance \\ - Inclusion in PubMed, CAS, Scopus and Google Scholar \\ - Research which is freely available for redistribution \\ Submit your manuscript at www.biomedcentral.com/submit}

